\title{
Management of Engineering Physics Learning in the Electrical Engineering Education Study Program Fakultas Teknik Universitas Negeri Medan
}

\author{
Rosnelli $^{1^{*}}$, Dadang Mulyana ${ }^{1}$ \\ \{*rosejitu62@gmail.com, dadang@unimed.ac.id\} \\ ${ }^{1}$ Faculty of Engineering, Universitas Negeri Medan, Indonesia
}

\begin{abstract}
Management of Physics Engineering learning is a development research to develop an appropriate learning model design for the study of Engineering Physics in the Electrical Engineering Education program of the Fakultas Teknik Universitas Negeri Medan. The research method used is Research and Development. The research sample is students who actively carry out learning Physics Engineering. Observation techniques and documentation studies are used to analyze learning needs and design learning models. Interviews, questionnaires and class observation sheets are used to see the success of the learning process. The test of student learning outcomes is used to see the effectiveness of the developed learning model prototype. The results of the implementation of the learning model indicate that student learning outcomes tend to be high. The application of Physics learning management that utilizes various sources can improve student competence. the application of physics learning management by utilizing e-learning can improve student competence beyond the graduation limit. The use of computer simulations can increase motivating students in learning. However, there are still $3 \%$ of students categorized as not competent because they are not used to learning by using e-learning facilities and computer simulation.
\end{abstract}

Keywords: Development of learning models, technical physics competencies, student learning outcomes

\section{Introduction}

Suggests that management refers to the process of coordinating and integrating work activities to be completed efficiently and effectively with and through other people [1]. Management of Physics Engineering learning is intended to develop interactive learning models in an effort to streamline and streamline the learning of Engineering Physics so as to improve student competence. Student activities in learning can encourage students to think creatively, convey information through group discussions. Lack of practicum equipment, can be overcome through the use of computer and internet simulations that can be accessed by students about the learning material. The interactive learning model developed will shape student learning habits through discussion of material in theory, practicum, and computer simulation. Student competence can be increased through the percentage of group learning activities, learning to express opinions and provide arguments against other groups, learn to listen and respect the opinions of other friends. Activities in interactive learning models can foster students' critical thinking through computer simulation activities in the learning process. 
The implementation of interactive learning models, allowing students to use soft were physics applications that can be simulated on a computer monitor. The use of computer simulations can make it easier for students to understand learning material. The use of computer simulations can make it easier for students to solve the problems of Physics Engineering courses found in their daily lives. The development of interactive learning models will be able to improve the Engineering Physics competency of students in the Electrical Engineering Education Study Program, Medan State University. This is relevant to the results of [2] study which explains that interactive learning models can improve student competence in audio video expertise programs at SMK Negeri 4 Medan.

\section{Methodology}

[3] Explains that education management means as a systematic, systematic, and comprehensive collaboration process in order to realize the goals of national education. Based on its main function, the term management has the function of a) planning, b) organizing, c) leading and controlling [4]. Planning is a management function that includes the process of defining objectives, establishing strategies to achieve these goals and devising plans to integrate and coordinate a number of activities. Organizing is a management function that includes the process of determining what tasks to do, who should do, how to classify those tasks, who must report to whom, and where decisions must be made or at what level the decision must be made. Leading is a management function that includes motivating subordinates, influencing individuals or groups as they work, having the most effective communication channels and solving in various ways employee behavior problems. Controlling is a management function that includes monitoring actual performance, comparing actual to standard, and making corrections.

Management of learning Physics The technique meant in this study is the process of utilizing learning tools and supporting facilities for learning Physics effectively and efficiently. Effective means to help students and lecturers in the learning process to develop knowledge and skills. Efficient means to use energy, time, cost, and other facilities as economically as possible. The interactive learning model is supported by the learning theory proposed by Joice (2000) that in fact the core learning activities must be directly aimed at helping students achieve the most important basis of learning activities namely "how to learn" and "learning by doing". Relevant to these opinions as explained by Shank quoted by [12] to learn something apply the theory that you have gained in everyday life or do exercises to improve learning outcomes. For this reason, a learning model is needed that can improve student learning outcomes. With regard to learning as a system Endang (2000) and Vienna (2006) explain that the quality of graduates or learning outcomes depends on the components of the system itself, namely the input / input components, process components and output / output components.

The concept of an interactive learning model that includes activities: 1) didactic procedures, which determine the activities carried out by the lecturer during the learning process takes place, so that students achieve instructional goals in the most effective way possible, 2) learning media, 3) forms of student learning with pay attention to individual abilities [6][7][8]. In the context of classroom learning and curriculum development at the micro level, the position and position of the development of interactive learning models for 
learning activities have been followed by students who are directed to the development of students so that students can study independently.

[9] provides an understanding for the development of learning models as the three activities as follows: 1) Design for an instructional developer to function as blue print or blu print for building experts; 2) Production which means the use of design to make instructional programs; 3) Validation which is the determination of the quality or validity of the final product resulting from the development of the learning model. Relevant to the above opinion [10] suggests that the learning model is a conceptual framework that describes systematic procedures in organizing learning experiences to achieve specific learning goals, and serves as a guide for learning designers and instructors in planning and implementing teaching and learning activities .

[11] Explain that whatever learning model is designed and developed, it must be realized that the main goal of learning is to help students develop the skills they need to work productively in order to increase the broader spectrum of various learning approaches. Next, Joyce \& Weil explained that the whole learning activity must be directly aimed at helping students achieve the most important basis of learning activities, namely "how to learn" and "learning by doing". From the results of a study of various teaching and learning models that have been specifically developed and tested by education experts, [11] suggest that learning models or learning models have elements: 1) Syntagmatics; 2) Social System; 3) Reaction Principle; 4) Support System; 5) Instructional Impact and Companion Impact.

Planning and development of the model begins with a literature review and pre-survey, namely research and information gathering, including literature review, learning observation that aims to analyze and determine the basic competencies that must be owned by 52 students of the Department of Electrical Engineering Education. The matter stated was in accordance with product development research using Dick \& Carey learning design development [12]. In this study the first was carried out with the research cycle of the development of "the R \& D Cycle" [13]. The results of the field survey will be used as an information source for designing interactive learning models. The results of the development were revised based on expert team input. After the field trial, the learning model and learning strategy were revised based on the input of the expert team to get the management of Engineering Physics learning.

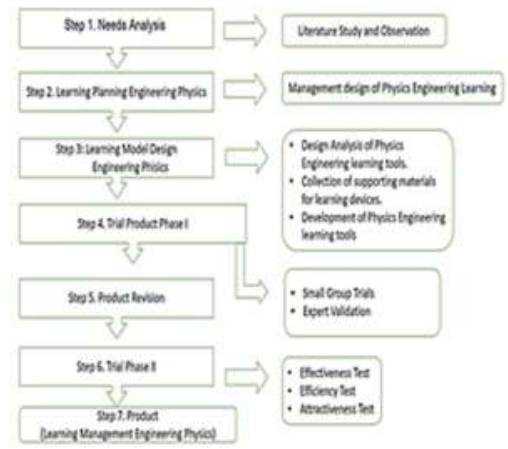

Fig. 1. Model Development of Management of Engineering Physics learning. Adaptation of Gall, Borg and Gall (1996).

The syntactic Engineering Physics learning model developed in an effort to improve student competence in the study of Engineering Physics in the Department of Electrical Engineering is as follows. 


\subsection{First Stage: Orientation}

The orientation phase starts from explaining the learning objectives to be achieved, explaining the mechanism of learning in an interactive learning model, giving motivation to students to be able to learn independently and in groups, explaining to students how to use computer media as learning support, learning group sharing. Each learning group consists of students with varying competencies.

\subsection{Study group stage}

The learning group stage begins with the student setting sitting in groups according to the learning group. Distributing learning material to be presented by students according to the schedule and observation assessment sheet. Students in groups together understand the learning material that has been shared. Students are allowed to bring other learning resources related to learning material. Solving problems discussed in groups can be done by students through practicum or using computer simulations in accordance with learning materials and learning needs agreed upon in the Lecture Program Unit that has been established and agreed upon by lecturers and students,

\subsection{Interactive stage}

The interactive stage starts from one of the learning groups presenting the assigned tasks. The Pangamat group began to fill in activity observation sheets carried out by groups presenting their assignments. After finishing the percentage, an interactive activity is carried out between the presenter and the observer group. Interactive between the presenter group and the observer group was based on observations on the lecture material presented, both based on practicum and based on computer simulations. Lecturers provide direction if necessary. The percentage group makes conclusions about learning material that is discussed in theory, practice and computer simulation.

\subsection{Transfer Phase}

The transfer phase starts from the lecturer collecting observer group observation sheets. Lecturers analyze the results of the student's overall obsession. Lecturers provide reinforcement of the material that has been discussed together. The lecture provides examples of material applications. Lecturers provide reinforcement about the conclusions given by students. The lecturer recalls the material that will be discussed the following week.

\section{Results and Discussion}

Data on the implementation of interactive learning models in field test 1 can be seen in the following table.

Table 1. Data from the Field Trial 1

\begin{tabular}{lcc}
\hline \multicolumn{1}{c}{ Student Group } & Number of Student & Precentage \\
\hline Not Compentent & 28 & $53,8 \%$ \\
Enough Compentent & 11 & $21,2 \%$ \\
Compentent & 10 & $19,2 \%$ \\
Very Compentent & 3 & $5,8 \%$ \\
\hline
\end{tabular}


From the results of observations of lecturers, and students found the impression that the implementation of interactive learning models is still not implied in accordance with expectations, and felt quite heavy for lecturers to motivate students to be interactive with the study groups who presented their group assignments. This is because students do not prepare themselves for the lecture material that has been determined in accordance with the agreed college contract. After being revised based on field trial 1, the learning model continues to field trial 2 and the results of the implementation can be seen in the following table.

Table 2. Field Test Results Data 2

\begin{tabular}{lcc}
\hline \multicolumn{1}{c}{ Student Group } & Number of Student & Precentage \\
\hline Not Compentent & 6 & $11 \%$ \\
Enough Compentent & 11 & $21 \%$ \\
Compentent & 18 & $35 \%$ \\
Very Compentent & 17 & $33 \%$ \\
\hline
\end{tabular}

From the results of the observations of the lecturers, and students, the impression was that the implementation of the interactive learning model had not been implied in accordance with expectations. There has been an increase in student learning outcomes, because students have implemented mini research for field applications. In addition to facilitating student understanding, they want more examples of application of Engineering Physics from everyday life to further accelerate students' understanding of lecture material in accordance with the applicable curriculum. After being revised based on field test 2, the learning model continued to field trial 3 , the results of which can be seen in the following table.

Table 3. Field Test Results Data 3

\begin{tabular}{lcc}
\hline \multicolumn{1}{c}{ Student Group } & Number of Student & Precentage \\
\hline Not Compentent & 2 & $3 \%$ \\
Enough Compentent & 12 & $25 \%$ \\
Compentent & 18 & $34 \%$ \\
Very Compentent & 20 & $38 \%$ \\
\hline
\end{tabular}

The achievement of the student's final score is then converted to the benchmark reference assessment that has been determined by Unimed with a range of 90-100 = A (very competent), $80-89=\mathrm{B}$ (competent), 70-79 = C (quite competent), $\leq 69=\mathrm{E}$ (incompetent), then the condition of students who take Physics I courses using interactive learning models is as follows.

Table 5. Percentage of Student Success

\begin{tabular}{ccccc}
\hline No & Range of value & Number of Student & $\%$ & Description \\
\hline 1 & $90-100$ & 20 & 38 & Very Compentent \\
2 & $80-89$ & 18 & 34 & Compentent \\
3 & $70-79$ & 12 & 25 & Quite Compentent \\
4 & $\leq 69$ & 2 & 3 & Not Compenten \\
\hline
\end{tabular}

The results of the management of Engineering Physics learning in an effort to increase the competence of students in the Electrical Engineering Department showed a significant increase. The application of Physics learning management that utilizes various sources can improve student competence. the application of physics learning management by utilizing elearning can improve student competence beyond the graduation limit. The use of computer simulations can increase motivating students in learning. However, there are still $3 \%$ of 
students categorized as not competent because they are not used to learning by using elearning facilities and computer simulation.

Management of learning Physics The techniques applied to improve student competence by forming study groups consisting of 5 students who chose their own friends to work together in the beajar group led them to be more interactive in their discussions. The results of field test data show that student achievement shows an increase from field trial 1, followed by field trial 2 and field trials 3 . The results of student questionnaires show that students feel that time runs so fast and students like interactive learning models. In addition, the impact of the accompanying interactive learning model is that students become more confident, can communicate verbally as students present their group's work in front of the class and interact interactively with the learning groups that have been formed. Thus, it can be said that the development of interactive learning models can improve students' competence in learning Physics Engineering.

Based on the results obtained as stated above, the implementation of this teaching grant has basically reached the goal of implementing teaching grants. Engineering Physics lecturers have also been able to design and implement interactive learning models to improve student competencies in Engineering Physics courses. Engineering Physics Learning by using interactive learning models makes learning processes meaningful for students, because interactive learning processes have an accompanying impact such as students can have the nature of initiative, critical thinking, willingness to learn, polite in oral communication, ability to analyze, solve problems, good work in teams, listening skills, time management, can summarize and have an independent nature. In addition, a test is also produced for the results of learning Physics Techniques that can be used to test the results of Physics Engineering learning for parallel classes.

\section{Conclusion}

Engineering is the process of utilizing learning tools and supporting facilities for learning Physics Engineering effectively and efficiently in order to support learning activities in the classroom through the development of interactive learning models. The learning tools in question are college contracts, lecture event units, guidelines for 6 student assignments which include routine assignments, critical book reports, critical journals, mini research, engineering ideas and projects. Supporting facilities in question are practical facilities and infrastructures in workshops, teaching materials, internet, computer simulations, lecturer e-mails and e-mails for students and other facilities. Management of Engineering Physics Learning in the Electrical Engineering Education Study Program Faculty of Engineering Medan State University can improve student competence through the implementation of interactive learning models. The syntax of interactive learning models is orientation, group learning, interactive and transfer. Intructional impacts of interactive learning models are learning outcomes that are achieved directly by directing students to the expected goals of student learning outcomes. Companion impact is other learning outcomes that result from a teaching and learning process or learning process, as a result of the creation of a learning atmosphere that is experienced directly by students without direct guidance from lecturers, such as initiative, critical thinking, willingness to learn, oral communication, ability to analyze, solve problems, good cooperation in teams, listening, polite in speaking, time management, can summarize the material and be independent 


\section{References}

[1] Robbin, Organizational Behavior. Australia: Thomson South Western, 2009.

[2] Rosnelli, Pengembangan Model Pembelajaran Interaktif Pada Program Keahlian Teknik Audio Video. Medan: Pascasarjana Unimed, 2008.

[3] R. Kreitner and K. Angelo, "Orgnizational Behavior," Mc Graw-Hill Int., 2007.

[4] J. W. Slocum and D. Hellrigel, Fundamental of Organizational Behavior. Australia: Thomson South Western, 2009.

[5] G. Dryden and J. Vos, Revolusi cara belajar the interaktif (terjemahan). Bandung: Kaifa, 2003.

[6] N. Syafruddin, Model Pembelajaran yang Memperhatikan Keragaman Individu Mahasiswa dalam Kurikulum Berbasis Kompetensi. Jakarta: Quantum Teaching, 2005.

[7] O. Hamalik, Sistem Pembelajaran Jarak Jauh dan Pembinaan Ketenagaan. Bandung: Trigenda Karya, 1994.

[8] S. Wen, Future of Education (Masa Depan Pendidikan). Alih Bahasa Arvin Saputra. Batam: Lucky Publisher, 2003.

[9] T. Sukamto, Teori Belajar dan Model-model Pembelajaran. Jakarta: Pusat Antar Universitas, 1997.

[10] U. Saripudin Winataputra, Model-model Pembelajaran. Jakarta: Pusat Antar Universitas, 1997.

[11] B. Joyce and M. Weil, Models of Teaching. New Jersey: Prentice-Hall, Inc., 2000.

[12] W. Dick and L. Carey, The systematic desaign of instruction (4ed). New York: Harper Collins Publisher, 1996.

[13] M. D. Gall, W. R. Borg, and J. P. Gall, Educational research: An introduction, 6th ed. 1996. 